Sains Malaysiana 50(9)(2021): 2549-2561

http://doi.org/10.17576/jsm-2021-5009-05

\title{
Evaluation of Trichoderma asperellum B1902 in Controlling Fusarium Wilt of Cavendish Banana Cultivar
}

(Penilaian Trichoderma asperellum B1902 dalam Mengawal Layu Fusarium pada Kultivar Pisang Cavendish)

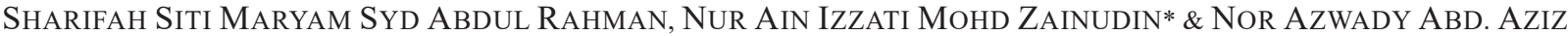

\begin{abstract}
Trichoderma species is one of the microorganisms with antagonistic properties as biological control agents. In the banana industry, Fusarium wilt disease caused by Fusarium oxysporum $f$. sp. cubense (Foc) has been practically managed using chemical pesticides that led to environmental disruptions, ineffective conditions and disease resistance. In preliminary study, T. asperellum gave better result compared to other species in inhibiting the growth of Foc in in vitro condition. Therefore, the aim of this study was to examine the effects of T. asperellum as a biological control of Fusarium wilt disease of banana. A total of 326 fungal isolates were isolated from soil samples obtained around Malaysia and identified as Trichoderma species based on phenotype characteristics. The species identity for the best candidates from dual culture test was confirmed based on internal transcribed spacers (ITS) and translation elongation factor 1 alpha (TEF-1 $\alpha)$ sequence identity. In dual culture test, findings showed that three isolates with a high percentage inhibition of radial growth (PIRG) were observed in plates of T. asperellum isolates B1902 (84.85\%), T2007 (77.78\%) and C1667 (75.76\%), which successfully inhibited the growth of F. oxysporum $f$. sp. cubense isolate 9888 . Based on in vivo test, the best candidate was T. asperellum B1902 with lower disease severity index (DSI) value of 0.2 compared to the inoculated control with DSI of 3.6. As a conclusion, T. asperellum B1902 can be used as an alternative treatment in managing Fusarium wilt disease. Hence, future study should be focused on applying T. asperellum as a biocontrol agent in the field and controlling other plant diseases in the agricultural plantation.
\end{abstract}

Keywords: Biological agent; Fusarium oxysporum; Malaysia; Panama disease

\section{ABSTRAK}

Spesies Trichoderma ialah salah satu mikroorganisma yang memiliki sifat antagonis sebagai agen kawalan biologi. Dalam industri tanaman pisang, penyakit layu Fusarium yang disebabkan oleh Fusarium oxysporum $f$. sp. cubense (Foc) dikawal menggunakan racun kimia yang boleh menyebabkan kesan negatif kepada persekitaran, tidak berkesan dalam sesetengah keadaan dan rintangan penyakit. Oleh itu, objektif kajian ini adalah untuk mengenal pasti kesan T. asperellum sebagai kawalan biologi penyakit layu Fusarium pada pisang. Sebanyak 326 pencilan telah dipencilkan daripada sampel yang diperoleh di sekitar Malaysia dan dikenal pasti sebagai spesies Trichoderma berdasarkan ciri fenotip. Pencilan terbaik yang dikenal pasti daripada ujian dwikultur disahkan identiti spesiesnya melalui analisis jujukan mentranskripsi jarak dalaman (ITS) dan translasi pemanjangan faktor 1-alfa (TEF-1 $\alpha$ ). Untuk uji kaji dwikultur, pemerhatian mendapati nilai peratus perencatan pertumbuhan radius (PIRG) tertinggi dapat diperhatikan pada kultur T. asperellum pencilan B1902 (84.85\%), T2007 (77.78\%) dan C1667 (75.76\%) yang berjaya merencatkan pertumbuhan pencilan Foc 9888. Berdasarkan uji kaji secara in vivo, pencilan terbaik adalah T. asperellum $B 1902$ dengan nilai indeks keseriusan penyakit (DSI) 0.2 berbanding kawalan pada 3.6. Sebagai kesimpulan, T. asperellum B1902 berpotensi digunakan sebagai rawatan alternatif dalam mengawal penyakit layu Fusarium. Oleh itu, kajian akan datang perlu memfokuskan kepada aplikasi T. asperellum sebagai agen biokawalan di persekitaran lapangan pertanian yang sebenar.

Kata kunci: Agen biokawalan; Fusarium oxysporum; Malaysia; penyakit Panama 


\section{INTRODUCTION}

In terms of gross value of production, banana is the fourth most important food crop in the developing world after rice, wheat and corn (Crop Trust 2014). However, banana plantation worldwide has been infected by Fusarium wilt which caused by the soil-borne fungus, Fusarium oxysporum f. sp. cubense (Foc) (Ploetz 2006; Su et al. 1986). This phenomenon gave a big impact to banana plantation as the soil-borne fungus cannot be controlled since it can remain in the soil for many years.

Tropical race 4 (TR4) is the name given to the Foc strain infecting Cavendish cultivars. In 1967, the strain TR4 was isolated from infected samples in Taiwan (Molina et al. 2009; Su et al. 1986). Recently, reclassification of TR4 into the new species $F$. odoratissimum was proposed by Maryani et al. (2019) based on phylogenetic analysis of the translation elongation factor-1alpha (tef1), the RNA polymerase II largest subunit (rpbl) and the RNA polymerase II second largest subunit ( $r p b 2$ ) of Foc isolates in the Indonesian centre of origin.

In the early 1990s, the susceptibility of Cavendish cultivars was emphasised when the newly established plantations were destroyed by the fungus in Malaysia and Indonesia (Buddenhagen 2009). Starting from that, TR4 has been found in Borneo and in Kalimantan, Sulawesi and Java islands. In Malaysia, this lethal disease was firstly reported in 1992 spreading on banana plantation in Nam Heng, Johor. An outbreak of the disease caused a lot of damages and losses (Lee et al. 1999). The disease has then spread throughout Peninsular Malaysia swiftly, causing more losses and damages to the banana industry.

For disease management practices, two major strategies that can be successfully used in controlling Fusarium wilt of banana are disease prevention and the use of resistant varieties (Gang et al. 2013). In the past years, plant tissue culture and phytosanitary practices have been applied to keep banana fields free from diseases. Many farmers extensively used chemical pesticide to control the crops from being infected by the pathogen, which remain ineffective for the time being since pathogen produces chlamydospores for survival over a long period.

At the moment, understanding on the disease protections and treatments for the crops are increasing as scientists have come out with several solutions. One of the common approaches is introducing microorganism that can act as a biological control against pathogens.
Malaysia is also listed as one of the countries that try to find out new solutions in progressive research on the biological control of disease. Trichoderma species could enhance growth of plants, control plant pathogens and act as a biopesticide agent in relieving chemical approaches (Angel et al. 2016; Ghazalibiglar et al. 2016; Hermosa et al. 2012; Kim \& Knudsen 2013; Li et al. 2017; Nur Ain Izzati \& Abdullah 2008; Suhaida \& Nur Ain Izzati 2013).

Recent studies were mostly applied on T. harzianum, which showed good results in biological control of many pathogens (Gveroska \& Ziberoski 2012; Kim \& Knudsen 2013; Thangavelu et al. 2004). However, based on a preliminary screening study conducted, T. asperellum gave better result in inhibiting the growth of Foc in vitro, and treating Fusarium wilt disease of banana under plant house conditions compared to T. harzianum. The objectives of this study were to evaluate antagonistic Trichoderma species against $F$. oxysporum f. sp. cubense and examine the efficacy of T. asperellum as a biocontrol agent of Fusarium wilt disease of banana.

\section{Materials AND Methods}

\section{FUNGAL SOURCE, ISOLATION AND PURIFICATION}

Fungal cultures were isolated from 11 soil sampling locations in seven states in Malaysia including Kedah, Melaka, Negeri Sembilan, Pahang, Selangor, Terengganu, and Sabah. About 200 grams of the soil samples were collected at a depth of $10 \mathrm{~cm}$ in triplicate using a sterile trowel. The fungi were isolated using soil dilution and grown on Rose Bengal Agar (RBA). Single spore isolation was carried out on new plates of potato dextrose agar (PDA) to obtain a pure culture of fungi. A causal agent culture (Foc isolate 9888) was obtained from Universiti Sains Malaysia (USM). Foc isolate 9888 was originally isolated from Fusarium wilt infected banana, a variety of Cavendish in Terengganu. Based on pathogenicity test, the isolate was pathogenic towards banana plant and caused Fusarium wilt (Unpublished data).

\section{IDENTIFICATION OF FUNGAL ISOLATES BASED ON MORPHOLOGICAL CHARACTERISTICS}

A total of 326 fungal isolates were tentatively identified into genus level of Trichoderma based on macro- and micromorphological characteristics according to the 
identification method described by Samuels et al. (2010) and Seydametova et al. (2010).

\section{MOLECULAR IDENTIFICATION OF SELECTED Trichoderma ISOLATES}

Three chosen Trichoderma isolates that showed the highest percentage inhibition of radial growth (PIRG) were subjected to species identification using internal transcribed spacer (ITS) and translation elongation factor (TEF) $1 \alpha$ sequence analyses. The isolates were subcultured on PDA and incubated for 3 days at $28 \pm 2{ }^{\circ} \mathrm{C}$. The genomic DNA (gDNA) was extracted using UltraClean ${ }^{\circledR}$ Microbial DNA Isolation Kit (MO BIO, Carlsbad, CA, USA) following the suggested manufacturers' protocol.

PCR amplification of ITS region and TEF-1 $\alpha$ was performed with a volume of $25 \mu \mathrm{L}$ reaction master mix that contained $5 \mu \mathrm{L}$ of $5 \times$ PCR buffer, $1.25 \mu \mathrm{L}$ of $0.5 \mu \mathrm{M}$ primer, $2.5 \mu \mathrm{L}$ of $0.2 \mathrm{mM}$ deoxynucleotide triphosphate (dNTPs), $2.5 \mu \mathrm{L}$ of $2.5 \mathrm{mM}$ magnesium chloride $\left(\mathrm{MgCl}_{2}\right), 0.125$ unit of Taq Polymerase (Promega, Madison, WI) and 20 ng of DNA template. The set of primers used for ITS region amplification were ITS 1 ( 5 '-TCCGTAGGTGAACCTGCGG-3') and ITS4 (5'-TCCTCCGCTTATTGATATGC-3') primer pairs (White et al. 1990) while for $T E F-1 \alpha$ were EF1728F (5'-CATCGAGAAGTTCGAGAAGG-3') and TEF1LLErev (5'-AACTTGCAGGCAATGTGG-3') primer pairs (Jaklitsch \& Voglmayr 2015). PCR cycling for ITS was conducted following the programme comprising initial denaturation at $95{ }^{\circ} \mathrm{C}$ for $30 \mathrm{~s}$, followed by 35 cycles of denaturation at $95{ }^{\circ} \mathrm{C}$ for $10 \mathrm{~s}$, annealing at $55^{\circ} \mathrm{C}$ for 15 s, extension at $72{ }^{\circ} \mathrm{C}$ for $30 \mathrm{~s}$ and final extension at $72{ }^{\circ} \mathrm{C}$ for $5 \mathrm{~min}$. The PCR cycling for $T E F-1 \alpha$ consisted of initial denaturation at $94{ }^{\circ} \mathrm{C}$ for $85 \mathrm{~s}$, followed by 35 cycles of denaturation at $95{ }^{\circ} \mathrm{C}$ for $35 \mathrm{~s}$, annealing at $58{ }^{\circ} \mathrm{C}$ for 55 s, extension at $72{ }^{\circ} \mathrm{C}$ for $90 \mathrm{~s}$, final extension at $72{ }^{\circ} \mathrm{C}$ for $10 \mathrm{~min}$ and left at $4{ }^{\circ} \mathrm{C}$ in a TProfessional Standard Thermocycler (Biometra Company, Biometra $\mathrm{GmbH}$, Gottingen, Germany) until use.

The PCR products were electrophoresed using $1.5 \%$ agarose gel with $0.1 \%$ FloroSafe DNA. The amplicon sizes for ITS regions and TEF-1 $\alpha$ gene were expected to be between 550 and $600 \mathrm{bp}$ and 1.0 to 1.2 $\mathrm{kb}$. A 100 bp DNA Ladder was used as a marker (Thermo Fisher Scientific, Carlsbad, California). The PCR products were later purified using QIAGEN (QIAquick ${ }^{\circledR}$ Gel Extraction Kit) following the manufacturer's instructions. The purified PCR products were sent to
MyTACG (MyTACG Bioscience Enterprise, Selangor, Malaysia) for sequencing using Thermofisher Scientific Genetic Analyzer ABI3730XL (SeqGen, Inc., CA, USA). Sequence similarity searches were performed on each of the representative fungal sequences using a standard nucleotide BLAST network services for similarities present in National Centre for Biotechnology Information (NCBI) database (Huang et al. 2009). ClustalW embedded in MEGA software version 7.0 was used to align the consensus sequence to each other and to the sequences in GenBank (Tamura et al. 2013). All sequences were deposited to GenBank database website (http://www.ncbi. nlm.nih.gov/).

\section{SCREENING OF Trichoderma ISOLATES AGAINST $F$. oxysporum f. sp. cubense}

All 326 Trichoderma isolates were challenged individually to determine their antagonistic activity against the pathogenic Foc isolate 9888 in a dual culture test. The inoculated plates were incubated for 5 days at $28 \pm 2$ ${ }^{\circ} \mathrm{C}$ (Siddiqui et al. 2008) in four replicates and repeated three times. The fungal growth was calculated using percentage inhibition of radial growth (PIRG) formula described by Siddiqui et al. (2008) as follows:

$$
\operatorname{PIRG}(\%)=\frac{R 1-R 2}{R 1} \times 100
$$

where R1 is the radius of the pathogen colony in control plate; and R2 is the radius of the pathogen colony in treatment plate.

Descriptive assessment of antagonist activity of Trichoderma isolates against $F$. oxysporum f. sp. cubense was scaled according to Sharfuddin and Mohanka (2012) as very high antagonist activity (>75 PIRG), high antagonist activity (61-75 PIRG), moderate antagonist activity (51-60 PIRG) and low antagonist activity $(<50$ PIRG).

\section{FUNGAL CULTURES AND PLANT PREPARATIONS}

Trichoderma isolates (B1902, C1667, and T2007) that showed the highest antagonistic effect on Foc isolate 9888 from dual culture test were evaluated for their effectiveness in suppressing Fusarium wilt of banana under plant house conditions. The daily temperature during this study was in the range of $30 \pm 2{ }^{\circ} \mathrm{C}$ with 50 to $70 \%$ relative humidity $(\mathrm{RH})$. Four-week old Cavendish 
banana cultivar seedlings developed from tissue-cultured plantlets were used in this study. The seedlings were purchased from Forest Research Institute Malaysia (FRIM). A mixture of topsoil, peat and sand at the ratio of $3: 2: 1(\mathrm{v} / \mathrm{v})$ were used as the medium for the young banana plants. About $1.5 \mathrm{~kg}$ of the mixture was put into each polyethylene bag with the size of $10 \times 10 \mathrm{~cm}$ until covering half of the young banana plant's depth.
The experiment was conducted in complete randomised design. The space between each plant was around $25 \mathrm{~cm}$ apart with $25 \mathrm{~cm}$ between rows. NPK fertiliser was given at week 0 to 6 following the manufacturer's recommendations and was watered manually using tap water once a day (Suhaida \& Nur Ain Izzati 2013). The young banana plants were divided into two controls and three treatments (Table 1). All plantlets were in 10 replicates for each treatment condition and repeated three times.

TABLE 1. Control and treatment of Trichoderma toward F. oxysporum f. sp. cubense (Foc) 9888

\begin{tabular}{lll}
\hline Experiment & Pathogen/Treatment & Application \\
\hline Negative control (-C) & no Foc/no treatment & $\mathrm{dH}_{2} 0$ \\
positive control (+C) & Foc/no treatment & $\mathrm{dH}_{2} 0$ \\
& Foc/B1902 & $\begin{array}{l}\text { Treated every two weeks starting from week } 0 \text { until week } \\
20\end{array}$ \\
T1 (B1902) & Foc/T2007 & Treated every two weeks starting from week 0 until week \\
& & 20 \\
T2 (T2007) & Foc/C1667 & Treated every two weeks starting from week 0 until week \\
& & 20
\end{tabular}

\section{PREPARATION OF CONIDIAL SUSPENSION}

Conidial suspension at the concentration of $1 \times 10^{7}$ conidia/mL of Trichoderma isolate was used following the method by Nur Ain Izzati and Abdullah (2008). Trichoderma isolates were cultured on PDA and incubated for 7 days at $28 \pm 2{ }^{\circ} \mathrm{C}$. Fungal conidia were harvested, and the mycelia debris was removed by filtration using sterile double-layered muslin cloth. The suspension was made up to $500 \mathrm{~mL}$ by adding sterile distilled water and adjusted to $1 \times 10^{7}$ conidia $/ \mathrm{mL}$ with the aid of haemocytometer. The fresh conidial suspension was watered on the soil at $500 \mathrm{~mL} / \mathrm{bag}$ every two weeks after acclimatisation.

The seedlings were inoculated with Foc isolate 9888 in week 3 after acclimatisation. The preparation of conidial suspension procedure was similar as mentioned before. However, the concentration was adjusted to $1 \times 10^{6}$ conidia/mL following Nur Ain Izzati and Salleh (2010) with modification for banana seedling where the root was soaked for $12 \mathrm{~h}$. The effects on disease development and severity were observed and recorded every week starting after the first inoculation week.

\section{DISEASE SEVERITY INDEX (DSI)}

After 7 days of inoculation, the plant conditions were recorded and scored for the discolouration of the leaves and height of the plant. The scoring was done weekly until week 20 using disease scale from 0 to 4 (Table 2) following the scoring system proposed by Thangavelu 
and Gopi (2015) with slight modification for the visible symptom recorded. On week 20, the corm of every plant was dissected to observe the internal symptoms of Fusarium wilt.

TABLE 2. Disease score used for disease assessment following Thangavelu and Gopi (2015) with modification for Fusarium wilt of banana

\begin{tabular}{ll}
\hline Disease score & Symptoms \\
\hline 0 & No symptom \\
1 & $1 \%-25 \%$ yellowish leaves (chlorosis), wilted leaves, stunted growth or stem discoloration \\
2 & $26 \%-50 \%$ yellowish leaves (chlorosis), wilted leaves, stunted growth or stem discoloration \\
3 & $51 \%-75 \%$ yellowish leaves (chlorosis), wilted leaves, stunted growth or stem discoloration \\
4 & $\begin{array}{l}76 \%-100 \% \text { yellowish leaves (chlorosis), wilted leaves, stunted growth, stem discoloration or plant dead/ } \\
\text { irreversible wilt }\end{array}$ \\
\hline
\end{tabular}

The severity of Fusarium wilt disease was calculated according to the modified formula by Mak et al. (2001):

\section{DSI: $\sum$ (scale $\times$ number of plants with the scale)}

$$
\sum \text { Number of plants per plot }
$$

From the calculation, DSI of the plants was classified and evaluated based on disease scale evaluation, which was 0 to 1 for resistance, 1.1 to 2.0 for tolerant, 2.1 to 3.0 for susceptible and 3.1 to 4.0 for highly susceptible (Mak et al. 2001).

\section{RE-ISOLATION OF PATHOGEN}

After the disease severity was scored at week 20, the tissues of all inoculated plants were re-isolated onto PDA and the fungus was re-identified by morphological characterisation.

\section{STATISTICAL ANALYSIS}

Data of PIRG and DSI of plants under plant house condition were analysed using one-way analysis of variance (ANOVA) in IBM SPSS Statistics version 21 to determine any statistically significant difference between the means of every Trichoderma species in inhibiting the growth of pathogen for PIRG and reducing DSI.

\section{RESULTS AND DISCUSSION}

\section{SCREENING OF Trichoderma ISOLATES AGAINST $F$.} oxysporum f. sp. cubense UNDER in-vitro CONDITION

In total, 326 Trichoderma isolates were successfully isolated from soil samples obtained throughout Malaysia (Table 3). All the isolates tested in this study were tentatively identified based on morphological characteristics. The isolated Trichoderma spp. had the ability to inhibit the mycelial growth of Foc isolate 9888 in a different range. Based on the percentage inhibition, the pattern was ranged between 33.33 and $84.85 \%$ (Table 3 ) where the highest PIRG value was shown by T. asperellum isolate B1902 (84.85\%). 
TABLE 3. Percentage of inhibition of radial growth (PIRG) and antagonistic activity of Trichoderma isolates

\begin{tabular}{|c|c|c|c|}
\hline $\begin{array}{l}\text { Trichoderma } \\
\text { species }\end{array}$ & Isolate no. & Mean of PIRG (\%) & $\begin{array}{l}\text { Antagonistic } \\
\text { activity }\end{array}$ \\
\hline \multirow[t]{4}{*}{ T. asperellum } & $\begin{array}{l}\text { B1581, B1584, B1893, B1894, B1902, B2104, } \\
\text { C1667, T2002, T2007 }\end{array}$ & $75.76-84.85$ & ++++ \\
\hline & $\begin{array}{l}\text { B28s, B30s, B131s, B139s, B142s, B1583, B1878, B1892, } \\
\text { B1898, B2096, B2098, B2106, B2107, } \\
\text { B2108, B2220, B2221, B2236, C256s, C261s, } \\
\text { C1660, C1661, C1666, C1669, C1670, C1671, } \\
\text { C1933, C1936, C1937, C1939, N327s, N2087, } \\
\text { T1989, T1996, T2008, T2015, T2051, T2055, } \\
\text { T2056 }\end{array}$ & $60.61-75.00$ & +++ \\
\hline & $\begin{array}{l}\text { A223s, B10s, B16s, B20s, B22s, B24s, B29s, } \\
\text { B95s, B98s, B99s, B134s, 170s, B302s, B2097, } \\
\text { B2218, B2219, B2223, B2228, B2229, B2230, } \\
\text { B2232, B2234, C1600, C1673, C1917, C1918, } \\
\text { C1923, C1926, C1934, C1938, N2083, N2086, } \\
\text { T64s, T66s }\end{array}$ & $51.52-59.38$ & ++ \\
\hline & A190s, A217s, B1958, B2226, B2227 & $43.33-48.48$ & + \\
\hline \multirow[t]{3}{*}{ T. hamatum } & $\begin{array}{l}\text { B26s, B2114, B2224, C1622, S1972, T2023, } \\
\text { T2072 }\end{array}$ & $60.61-70.59$ & +++ \\
\hline & S1978, S1984, T63s, Т2005, Т2025, Т2070, Т2071 & $51.61-58.82$ & ++ \\
\hline & S1975, S1981, S1983, S1986, T2016, T2041 & $40.30-50.00$ & + \\
\hline \multirow[t]{2}{*}{ T. harzianum } & $\begin{array}{l}\text { B1897, B1900, B2100, B2101, B2110, T1994, } \\
\text { T2042, T2069 }\end{array}$ & $75.76-81.82$ & ++++ \\
\hline & $\begin{array}{l}\text { B25s, B94s, B129s, B130s, B141s, B1586, B1882, B1885, } \\
\text { B1903, B1949, B1950, B1952, B1961, } \\
\text { B2099, B2109, B2116, B2222, C264s, C267s, } \\
\text { C1662, C1663, C1664, C1672, C1674, C1675, } \\
\text { C1919, C1935, C1941, N1630, N1631, N2084, } \\
\text { N2089, S1987, T69s, T73s, T83s, T1988, T1990, } \\
\text { T1992, T1993, T1995, T1997, T1998, T1999, } \\
\text { T2000, T2001, T2003, T2004, T2006, T2009, } \\
\text { T2010, T2011, T2012, T2013, T2014, T2017, } \\
\text { T2018, T2019, T2021, T2022, T2024, T2026, } \\
\text { T2028, T2030, T2032, T2034, T2035, T2039, } \\
\text { T2043, T2047, T2048, T2050, T2053, T2057, } \\
\text { T2058, T2059, T2061, T2062, T2063, T2076, } \\
\text { T2077, T2078 }\end{array}$ & $60.29-74.19$ & +++ \\
\hline
\end{tabular}


A240s, B8s, B112s, B144s, B151s, B155s, B158s, B159s,

B161s, B165s, B166s, B1879, B1880,

B1883, B1886, B1887, B1888, B1889, B1959,

B2105, B2111, B2113, B2117, B2238, C259s,

C1594, C1599, C1920, C1921, C1922, C1924,

C1927, C1929, C1931, C1940, C1942, C1944,

C1945, C1947, N317s, N2088, N2090, S1973,

S1979, S1980, T72s, T1991, T2020, T2027,

T2029, T2033, T2066, T2068, T2074, T2079

B136s, C1620, C1916, C1943, C1946, N2085,

$33.33-50.00$

S1971, S1976, S1985, T78s, T2064

\begin{tabular}{|c|c|c|c|}
\hline \multirow[t]{3}{*}{ T. koningiopsis } & $\begin{array}{l}\text { A221s, A237s, B149s, B154s, B296s, B1895, } \\
\text { B1896, B1899, B1901, B1904, B2112, B2217, } \\
\text { B2233, C269s, C1665, C1928, C1948, S1974, } \\
\text { T71s, T2045, T2054, T2060 }\end{array}$ & $60.61-69.70$ & +++ \\
\hline & $\begin{array}{l}\text { B19s, B128s, B138s, B156s, B305s, B2102, } \\
\text { B2231, C1932, T2037, T2065 }\end{array}$ & $51.72-60.00$ & ++ \\
\hline & B1884, B2103, B2225, C1925, Т2067 & $36.36-47.06$ & + \\
\hline H. rodmanii & M1891 & 69.12 & +++ \\
\hline \multirow[t]{3}{*}{ T. spirale } & T2031, T2044, T2080, T2082 & $64.61-69.23$ & +++ \\
\hline & T2049, T2075, Т2081 & $55.38-60.00$ & ++ \\
\hline & T2046 & 48.28 & + \\
\hline \multirow[t]{3}{*}{ T. virens } & $\mathrm{T} 2052$ & 75.76 & ++++ \\
\hline & $\begin{array}{l}\text { B101s, B108s, B304s, B1881, B1890, B2115, } \\
\text { T79s, T2073 }\end{array}$ & $60.61-69.70$ & +++ \\
\hline & C1601, C1613, C1614, C1615 & $53.23-56.45$ & ++ \\
\hline \multirow[t]{2}{*}{ T. viride } & B2235, B2237, K1968, K1970 & $63.64-69.70$ & +++ \\
\hline & T2040 & 41.18 & + \\
\hline
\end{tabular}

Figure 1 shows the inhibition zone caused by selected isolates to indicate every level of Trichoderma species in inhibiting the growth of Foc mycelia in dual culture test. The results were recorded after 5 days of incubation at room temperature. The PIRG of control plate (uninhibited growth of 9888) was $0 \%$. The lowest PIRG values were shown by T. harzianum (isolates S1971 and C1943) and T. koningiopsis (T2067) (Figure 1(B) - 1(D)). Examples of middle PIRG values (moderate antagonist activity) were shown by $T$. asperellum A223s, T. harzianum N1631 and H. rodmanii M1891 (Figure 1(E) - 1(G)). The highest PIRG (very high antagonist activity) values were shown by T. asperellum isolates (B1902, T2007, and C1667) (Figure 1(H) - 1(J)). With increasing incubation time, the mycelia of all Trichoderma isolates were fully overgrown on the pathogen colony and even sporulated on the Foc colony for space to live. 


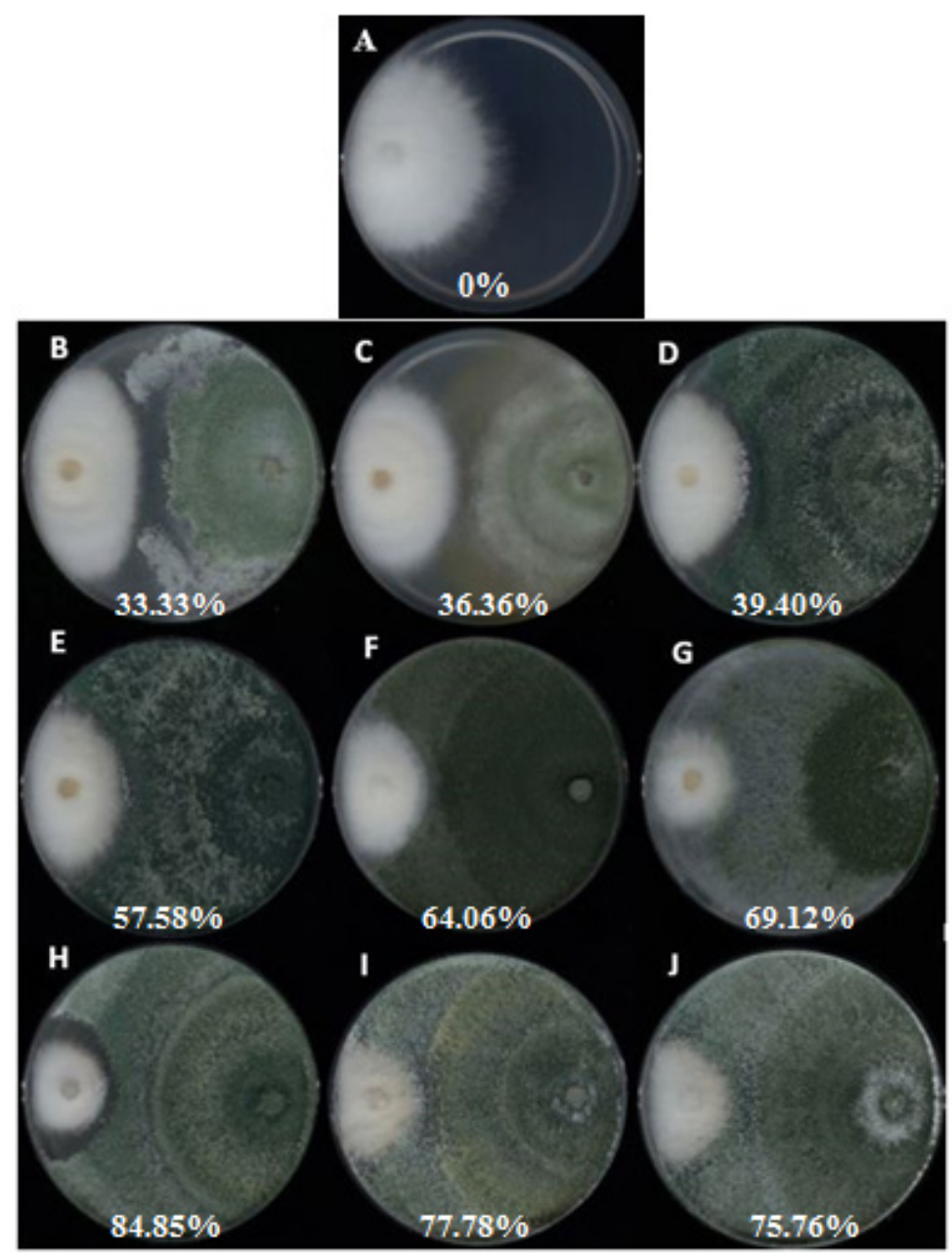

FIGURE 1. Effects of Trichoderma isolates on the radial growth of $F$. oxysporum f. sp. cubense isolate 9888 in dual culture test after 5 days of incubation. A: control; uninhibited growth of 9888 . The lowest PIRG values were shown by B: S1971, C: T2067, D: C1943. The middle PIRG values were shown by E: A223s, F: N1631, G: M1891 and the highest PIRG values were shown by H: B1902, I: T2007, J: C1667

Dual culture test is one of the primary steps to screen the effectiveness of every Trichoderma isolates on inhibiting the growth of Foc in the plate (Pakdaman et al. 2013). This test is a comprehensive experiment that exhibits the overall antagonistic potential of a fungal biological control agent and can be applied after preliminary fast screening tests (Pakdaman et al. 2013) as it is mainly a predictive tool to determine growth inhibition capability before carrying out time-consuming and more expensive study. All Trichoderma isolates gave a different degrees of PIRG value; even among the same species as every isolate had a different effect of controlling soil borne phytopathogen (Sharfuddin \& Mohanka 2012). The effectiveness of Trichoderma isolates can play vital roles in sustainable agriculture such as controlling phytopathogenic fungi, increasing plant growth, developing resistance against diseases and remediating polluted agricultural soils (Viterbo \& Horwitz 2010). 
The antagonistic interaction between Trichoderma species and pathogen includes direct and indirect mechanisms. Dual culture test interaction is a direct mechanism (mycoparasitism) (Benítez et al. 2004). The mycoparasitism interaction typically involves Trichoderma encountering the pathogen and attaching the pathogen by attraction, attachment, coiling around and lysis by hydrolytic enzymes after it dominates the pathogen. It slowly kills the pathogen by suppressing the pathogen growth and conquering the food and space
(Mukherjee et al. 2012). Trichoderma species grows faster than pathogens under the same conditions on PDA (Figure 1(B) - 1(J)), therefore, allowing Trichoderma to inhibit the growth of most plant pathogen. Out of 326 Trichoderma isolates screened in dual culture analysis, only three isolates showed very high PIRG values (T. asperellum B1902, C1667, and T2007), which were chosen for species confirmation using molecular characterisation and further in vivo test. The GenBank accession numbers of deposited sequences are listed in Table 4.

TABLE 4. GenBank accession number of ITS region and TEF Trichoderma isolates

\begin{tabular}{llllll}
\hline No. & Isolates & Location (city, state) & Scientific name & ITS & TEF \\
\hline 1. & B1902 & Dengkil, Selangor & T. asperellum & MG386281 & MG595715 \\
2. & C1667 & Maran, Pahang & T. asperellum & MG386283 & MG595716 \\
3. & T2007 & Bukit Besi, Terengganu & T. asperellum & MG386282 & MG595717 \\
\hline
\end{tabular}

T. asperellum AS BIOCONTROL AGENT OF FUSARIUM WILT OF BANANA UNDER PLANT HOUSE CONDITION

Experiment on the efficacy of T. asperellum as biocontrol agent of Fusarium wilt under plant house condition was repeated three times with similar results. Disease
Severity Index (DSI) of positive control kept increasing until 20 weeks of inoculation where the DSI value was 3.6 (Figure 2), which was highly susceptible to the disease and by the prediction, at late stage, all the plant will die. For negative control plants, there was no change

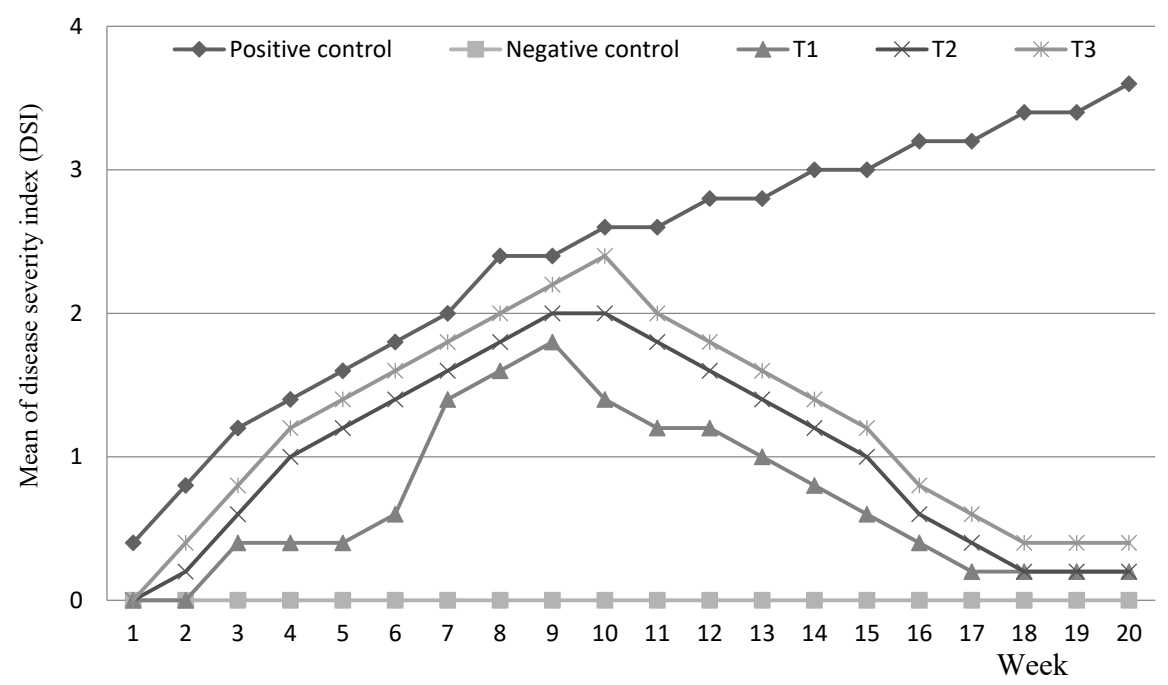

FIGURE 2. Mean of Disease Severity Index (DSI) in different conditions a week after inoculation of Fusarium oxysporum f. sp. cubense until 20 weeks of inoculation with every two-week application of T. asperellum treatment T1 (B1902), T2 (T2007) and T3 (C1667) 
and DSI value remained at 0 as they grew normal since no pathogen was inoculated. All the applications of the conidia gave positive effects on the banana plants. As shown in Figure 2, there was a reduction on the severity of Fusarium wilt disease on the selected banana plants treated with $T$. asperellum that have been applied for every two weeks in comparison with untreated positive control of banana plants. The DSI of T1 plants remained low till week 6 and suddenly increased dramatically at week 7. From the observation, on week 7 many leaves turned yellowish. However, prolonged incubation time did increase disease resistance of the tested plant as the plants strived to live, which was probably promoted by the Trichoderma.
From the plant house condition, the results were analysed using one-way ANOVA and the mean value showed $(p<0.05)$ that there was a significant difference among all treatments (positive control, negative control, T1 (B1902), T2 (T2007) and T3 (C1667)) of inoculation of Foc. The plants T1, T2 and T3 under treatments using T. asperellum with different isolates B1902, T2007 and C1667, respectively, for every two-week application, were decreased in DSI values at 20 weeks after inoculation. The suppression of T. asperellum towards Foc isolate 9888 was by a direct mechanism as T. asperellum and Foc as a pathogen were directly applied on the soil.

Based on Figure 3, negative control plants grew healthy with very green leaves and fresh stem and the
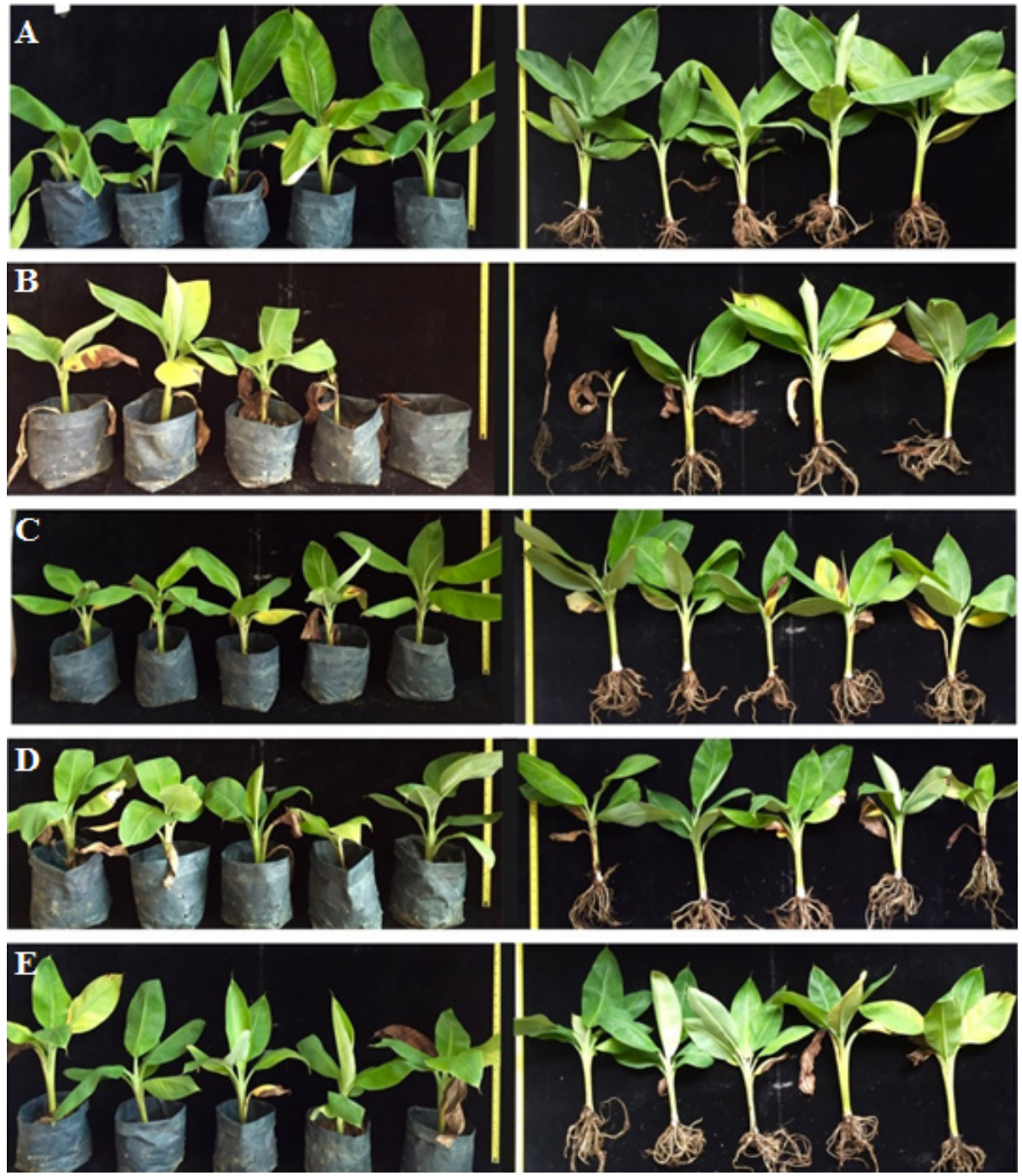

FIGURE 3. Fusarium wilt symptoms on banana plants treated with $T$. asperellum on week 20 post-inoculation. A: negative control, no disease symptoms on plants, B: positive control, artificially infected with Fusarium oxysporum f. sp. cubense and no treatment, visible symptoms of Fusarium wilt disease. C-E: Fusarium wilt suppression on banana plants treated with Trichoderma isolates. Treatments were given every two weeks with

Trichoderma isolate B1902 (T1), T2007 (T2) and C1667 (T3), respectively 

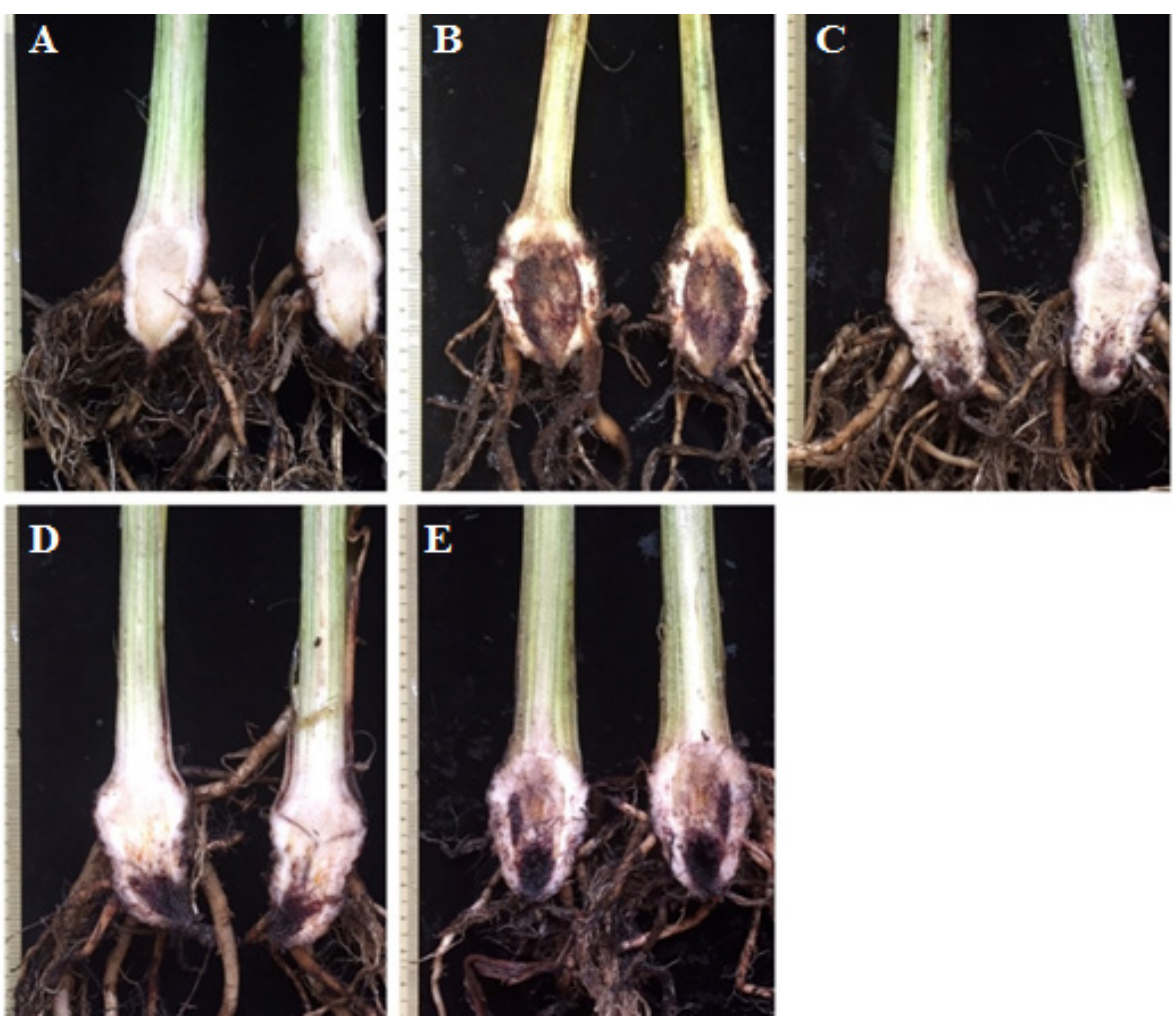

FIGURE 4. Basal parts (rhizome and stem) of control and treated plants on week 20 postinoculation showing the internal symptoms of Fusarium wilt with the reddish-brown colour tissues indicating the lesion from Fusarium oxysporum f. sp. cubense colonisation in the plant. A: Negative control showing no symptom and healthy corm. B: Positive control with a rotten corm due to the disturbed vascular system by Fusarium oxysporum $\mathrm{f}$. sp. cubense. C, D, E: Plants showing disease suppression effect on corm and plants treated with Trichoderma isolate B1902 (T1), T2007 (T2) and C1667 (T3), respectively

disease score was 0 . For positive control, the leaves showed around 80 to $90 \%$ yellowish and wilted symptoms. Their growth was stunted and their stems became blackened where some of them had died showing the disease scoring of 4.0. For T1 plants treated with $T$. asperellum (B1902), their condition was observed almost the same as negative control plants, but only two plants were affected with yellowish leaves. For T2 plants treated with T. asperellum (T2007), there were three plants affected with wilted leaves and stunted growth. For T3 plants treated with T. asperellum (C1667), four plants were affected with yellowish leaves (chlorosis), wilted leaves and stunted growth. Figure 4 shows the symptoms of Foc on the basal parts of banana plants treated with the selected T. asperellum on week 20 of post-inoculation. The corm of every plant was dissected to observe the internal symptoms of Fusarium wilt and the visible symptoms as shown.

Trichoderma starts attaching to the host by forming the appressoria- or papillae-like structures or hook shaped in contact or coiling with host hyphae (Mukherjee et al. 2012; Suhaida \& Nur Ain Izzati 2013). Since Fusarium cell wall is made up of chitin, using all the mechanism stated above, Trichoderma can penetrate and degrade its cell wall. Then, Trichoderma will utilise the intracellular content of host and gain nutrient from the pathogen by 
parasitism and deploying mycotoxins (Suhaida \& Nur Ain Izzati 2013).

Trichoderma strains are very efficient for the biocontrol of several pathogens or in plant growth promotion via rhizosphere colonisation (Vinale et al. 2008) or in providing nutrients to the plant. This study was performed using $T$. asperellum isolates with the potential for antagonism in vitro, which has also shown their ability to control diseases in plant house condition. However, the efficiency level verified in many field studies was lower than expected (Chagas et al. 2017). According to Chagas et al. (2017), some factors are important for achieving effective results with the biocontrol agents such as effective strains in the field against several phytopathogens, low production cost involving efficient formulations, form, dose, and time of application. Studies have shown that the application of $T$. asperellum to root system has successfully reduced the disease symptom up to $80 \%$ due to the production of chitinases, glucanases, peroxidases and cellulases by Trichoderma species (Yedidia et al. 2000). Based on previous studies, $T$. asperellum strain T34 has also suppressed the disease symptom of Fusarium wilt of carnation (Sant et al. 2010). Besides, T. asperellum has also successfully inhibited $F$. oxysporum f. sp. lycopersici that caused Fusarium wilt of tomato (El Komy et al. 2015).

\section{CONCLUSION}

As a conclusion, T. asperellum B1902 was the most effective isolate and has shown its ability to inhibit the growth of pathogen of $F$. oxysporum $\mathrm{f}$. sp. cubense under in vitro and in vivo conditions. For potential commercial use as a promising biological agent substituting chemical reagent in controlling plant diseases, it should be further studied and developed.

\section{ACKNOWLEDGEMENTS}

This work was funded by the Ministry of Higher Education under Fundamental Research Grant Scheme (FRGS/1/2018/STG03/UPM/02/12). Sharifah Siti Maryam Syd Abdul Rahman received a scholarship from the UPM Graduate Research Fund (GRF).

\section{REFERENCES}

Angel, L.P.L., Yusof, M.T., Ismail, I.S., Ping, B.T.Y., Azni, I.N.A.M., Kamarudin, N.H. \& Sundram, S. 2016. An in vitro study of the antifungal activity of Trichoderma virens
$7 \mathrm{~b}$ and a profile of its non-polar antifungal components released against Ganoderma boninense. Journal of Microbiology 54(11): 732-744.

Benítez, T., Rincón, A.M., Limón, M.C. \& Codón, A.C. 2004. Biocontrol mechanisms of Trichoderma strains. International Microbiology 7(4): 249-260.

Buddenhagen, I. 2009. Understanding strain diversity in Fusarium oxysporum f. sp. cubense and history of introduction of 'Tropical Race 4' to better manage banana production. Acta Horticulturae 828: 193-204.

Chagas, L.F.B., Chagas Junior, A.F., Fidelis, R.R., de Carvalho Filho, M.R. \& de Oliveira Miller, L. 2017. Trichoderma asperellum efficiency in soybean yield components. Comunicata Scientiae 8(1): 165-169.

Crop Trust 2014. The Crop Trust Annual Report 2014. Bonn, Germany.

El Komy, M.H., Saleh, A.A., Eranthodi, A. \& Molan, Y.Y. 2015. Characterization of novel Trichoderma asperellum isolates to select effective biocontrol agents against tomato Fusarium wilt. Plant Pathology Journal 31(1): 50-60.

Gang, G., Bizun, W., Weihong, M., Xiaofen, L., Xiaolin, Y., Chaohua, Z., Jianhong, M. \& Huicai, Z. 2013. Review: Biocontrol of Fusarium wilt of banana: Key influence factors and strategies. African Journal of Microbiology Research 7(41): 4835-4843.

Ghazalibiglar, H., Kandula, D.R. \& Hampton, J.G. 2016. Biological control of Fusarium wilt of tomato by Trichoderma isolates. New Zealand Plant Protection 69: 57-63.

Gveroska, B. \& Ziberoski, J. 2012. Trichoderma harzianum as a biocontrol agent against Alternaria alternata on tobacco. ATI - Applied Technologies and Innovations 7: 67-76.

Hermosa, R., Viterbo, A., Chet, I. \& Monte, E. 2012. Plantbeneficial effects of Trichoderma and of its genes. Microbiology 158(1): 17-25.

Huang, W.Y., Cai, Y.Z., Surveswaran, S., Hyde, K.D, Corke, H. \& Sun, M. 2009. Molecular phylogenetic identification of endophytic fungi isolated from three Artemisia species. Fungal Diversity 36: 69-88.

Jaklitsch, W.M. \& Voglmayr, H. 2015. Biodiversity of Trichoderma (Hypocreaceae) in Southern Europe and Macaronesia. Studies in Mycology 80: 1-87.

Kim, T.G. \& Knudsen, G.R. 2013. Relationship between the biocontrol fungus Trichoderma harzianum and the phytopathogenic fungus Fusarium solani f. sp. pisi. Applied Soil Ecology 68: 57-60.

Lee, Y.M., Teo, L. \& Ong, K.P. 1999. Fusarium wilt of Cavendish banana and its control in Malaysia. In Banana Fusarium Wilt Management: Towards Sustainable Cultivation, edited by Molina, A.B., Nik Masdek, N.H. \& Liew, K.W. Proceedings of the International Workshop on the Banana Fusarium Wilt Disease. Malaysia.

Li, R., Chen, W., Cai, F., Zhao, Z., Gao, R. \& Long, X. 2017. Effects of Trichoderma-enriched biofertilizer on 
tomato plant growth and fruit quality. Journal of Nanjing Agricultural University 40(3): 464-472.

Mak, C., Mohamed, A.A., Liew, K.W. \& Ho, Y.W. 2001. Early screening technique for Fusarium wilt resistance in banana micropropagated plants. In Banana Improvement: Cellular, Molecular Biology, and Induced Mutations, edited by Jain, S.M. \& Swennen, R. Leuven, Belgium: Science Publishers, Inc Enfield, USA. pp. 219-227.

Maryani, N., Lombard, L., Poerba, Y.S., Subandiyah, S., Crous, P.W. \& Kema, G.H.J. 2019. Phylogeny and genetic diversity of the banana Fusarium wilt pathogen Fusarium oxysporum f. sp. cubense in the Indonesian centre of origin. Studies in Mycology 92: 155-194.

Molina, A.B., Fabregar, E., Sinohin, V.G., Yi, G. \& Viljoen, A. 2009. Recent occurrence of Fusarium oxysporum f. sp. cubense tropical race 4 in Asia. Acta Horticulturae 828: 109-116.

Mukherjee, M., Mukherjee, P.K., Horwitz, B.A., Zachow, C., Berg, G. \& Zeilinger, S. 2012. Trichoderma-plant-pathogen interaction: Advances in genetics of biological control. Indian Journal of Microbiology 52(4): 522-529.

Nur Ain Izzati, M.Z. \& Salleh, B. 2010. Variability of Fusarium species associated with bakanae disease on rice in terms of their virulence, vegetative, and biological compatibilities. Sydowia 62(1): 89-104.

Nur Ain Izzati, M.Z. \& Abdullah, F. 2008. Disease suppression in Ganoderma infected oil palm seedlings treated with Trichoderma harzianum. Plant Protection Science 44: 101107.

Pakdaman, B.S., Goltapeh, E.M., Soltani, B.M., Talebi, A.A., Nadepoor, M., Kruszewska, J.S. \& Vannacci, G. 2013. Toward the quantification of confrontation (dual culture). Test: A case study on the biological control of Pythium aphanidermatum with Trichoderma asperelloides. Journal of Biofertilizers and Biopesticides 4(2): 1-5.

Ploetz, R.C. 2006. Fusarium wilt of banana is caused by several pathogens referred to as Fusarium oxysporum f. sp. cubense. Phytopathology 96(6): 653-656.

Samuels, G.J., Chaverri, P., Farr, D.F. \& McCray, E.B. 2010. Trichoderma online, systematic mycology and microbiology laboratory, ARS, USDA. Accessed on 16th November 2014

Sant, D., Casanova, E., Segarra, G., Avilés, M., Reis, M. \& Trillas, M.I. 2010. Effect of Trichoderma asperellum strain T34 on Fusarium wilt and water usage in carnation grown on compost-based growth medium. Biological Control 53: 291-296.

Seydametova, E., Hj. Kambol, R. \& Zainol, N. 2010. Morphological characterization of soil Penicillium sp. strains - potential producers of statins. Biotechnology Symposium IV 2010- Sabah, Malaysia.

Sharfuddin, C. \& Mohanka, R. 2012. In vitro antagonism of indigenous Trichoderma isolates against phytopathogen causing wilt of lentil. International Journal of Life Science and Pharma Research 2: 195-202.
Siddiqui, Y., Meon, S., Ismail, M.R. \& Ali, A. 2008. Trichoderma-fortified compost extracts for the control of Choanephora wet rot in okra production. Crop Protection 27: 385-390.

Su, H.J., Hwang, S.C. \& Ko, W.H. 1986. Fusarial wilt of Cavendish bananas in Taiwan. Plant Disease 70(9): 814-818.

Suhaida, S. \& Nur Ain Izzati, M.Z. 2013. The efficacy of Trichoderma harzianum $\mathrm{T} 73 \mathrm{~s}$ as a biocontrol agent of Fusarium ear rot disease of maize. International Journal of Agriculture and Biology 15: 1175-1180.

Tamura, K., Stecher, G., Peterson, D., Filipski, A. \& Kumar, S. 2013. MEGA6: Molecular evolutionary genetics analysis version 6.0. Molecular Biology and Evolution 30(12): 2725-2729.

Thangavelu, R. \& Gopi, M. 2015. Field suppression of Fusarium wilt disease in banana by combined application of native endophytic and rhizospheric bacterial isolates possessing multiple functions. Phytopathologia Mediterranea 54(2): 241-252.

Thangavelu, R., Palaniswami, A. \& Velazhahan, R. 2004. Mass production of Trichoderma harzianum for managing Fusarium wilt disease of banana. Agriculture, Ecosystems and Environment 103(1): 259-263.

Vinale, F., Sivasithamparam, K., Ghisalberti, E.L., Marra, R., Woo, S.L. \& Lorito, M. 2008. Trichoderma-plant-pathogen interactions. Soil Biology and Biochemistry 40: 1-10.

Viterbo, A. \& Horwitz, B.A. 2010. Mycoparasitism. In Cellular and Molecular Biology of Filamentous Fungi, edited by Borkovich, K. \& Ebbole, D.J. Washington: American Society for Microbiology. pp. 676-693.

White, T.J., Bruns, T., Lee, S. \& Taylor, J. 1990. Amplification and direct sequencing of fungal ribosomal RNA genes for phylogenetics. In PCR Protocols: A Guide to Methods and Applications, edited by Innis, M.A., Gelfand, D.H., Sninsky, J.J. \& White, T.J. San Diego: Academic Press. pp. 315-322.

Yedidia, I., Benhamou, N., Kapulnik, Y. \& Chet, I. 2000. Induction and accumulation of PR proteins activity during early stages of root colonization by the mycoparasite Trichoderma harzianum strain T-203. Plant Physiology and Biochemistry 38(11): 863-873.

Department of Biology

Faculty of Science

Universiti Putra Malaysia

43400 UPM Serdang, Selangor Darul Ehsan

Malaysia

*Corresponding author; email: ainizzati@upm.edu.my

Received: 20 February 2020

Accepted: 7 January 2021 